\title{
Distinguishing natural evolution and human impact on estuarine morpho-sedimentary development: A case study from the Vilaine Estuary, France
}

\author{
C. Traini ${ }^{\text {a }}$, J.-N. Proust ${ }^{\mathrm{b}}$, D. Menier ${ }^{\mathrm{a}, \mathrm{c}^{*}}{ }^{*}$, M.J. Mathew ${ }^{\mathrm{c}}$ \\ ${ }^{a}$ UMR CNRS 6538, Géosciences Marine \& Géomorphologie littorale, Université de Bretagne Sud, rue Yves Mainguy, 56017 Vannes cedex, France \\ b Géosciences (UMR 6118), CNRS and Université de Rennes 1, 35042 Rennes, France \\ c Universiti Teknologi PETRONAS Tronoh, Perak, Malaysia
}

\section{A R T I C L E I N F O}

\section{Article history:}

Received 2 January 2015

Received in revised form

15 June 2015

Accepted 22 June 2015

Available online 27 June 2015

\section{Keywords:}

Estuaries

Man-induced effects

Estuarine dynamics

Tidal flats

Salt marshes

Dams

\begin{abstract}
A B S T R A C T
Estuaries are coastal areas controlled by hydrodynamic factors such as sea-level changes, waves and tidal currents, and river discharge. This study focuses on the Vilaine Estuary which is strongly impacted by human activity after construction of Arzal dam in 1970. The purpose of this research is to differentiate the role of natural from anthropogenic factors on sediment dynamics within the Vilaine Estuary. We are proposing a hypothetical model based on the hydrodynamic modification and morpho-sedimentary development by analyzing the natural estuarine evolution and the impact of human alteration to the natural system by utilizing datasets including river discharge, tidal currents, winds and wave activities to further combine with photographic, bathymetric, topographic and sedimentary surveys. Results show that waves carry sediment from the sea and rework local sediments. The river damming is reducing the tidal prims and leads to the fall of tidal currents. This new situation supports the sediment deposition and reduces at the same time the accommodation space which decrease tidal currents in feed-back. The Vilaine Estuary is therefore coming close to a bay-type functioning which leads to a channel narrowing, a drastic increase of the tidal flat zone, an acceleration of erosional processes affecting the main channel, salt marsh and all associated depositional systems. We propose a hypothetical model showing that this evolution took place in two steps and we show that the dam has an effect to accelerate a natural infilling of the estuary.
\end{abstract}

(c) 2015 Elsevier Ltd. All rights reserved.

\section{Introduction}

Estuaries are remnants of ancient fluvial valleys that have succumbed to flooding due to eustatic variations. Estuarine environments are of profound interest to human population due to their intense biological (habitat, reproduction, nursery, migration path) and economical relevance (fishing, fish trade, tourism, harbour). Anthropological impacts strongly modify the natural (pre-human) balance of the environment in various ways (e.g. modification of river flow, degradation of the habitat, depletion of aquatic resources, pollution, etc.). Since 1960s, there has been a significant increase in research pertaining to estuaries (Guilcher,

\footnotetext{
* Corresponding author. Universiti Teknologi PETRONAS Tronoh, Perak, Malaysia.

E-mail addresses: camille.traini@yahoo.com, ct@gpi.uni-kiel.de (C. Traini), jeannoel.proust@univ-rennes1.fr (J.-N. Proust), dmenier5@gmail.com, david.menier@ univ-ubs.fr, david.menier@petronas.com.my (D. Menier), manoj_mathew7@yahoo. com (M.J. Mathew).
}

1958; Cameron and Pritchard, 1963; Bowden, 1967; Caspert, 1967; Pritchard, 1967; Fairbridge, 1980; Pethick, 1984; Day et al., 1989; Bird, 1993; Geyer et al., 2000; Woodruff et al., 2001; Guo and Levinson, 2007) with quite a few estuaries being thoroughly explored and utilized as references to elucidate hydrodynamics (Bilgili et al., 2005; Ji et al., 2007; Levasseur et al., 2007), sedimentology (Dalrymple et al., 1992; Allen and Posamentier, 1993, 1994; Martinsen and Hellandhansen, 1994; Estournès et al., 2012) and ecological balance (Caspert, 1967; Azevedo et al., 2008). However, integrated studies taking into account the role of human activities within these environments are scarce (Ferrier and Anderson, 1997; Winterwerp et al., 2001; Tagliani et al., 2003). This form of studies are often difficult to generalize (Hart and Long, 1990; Wolanski et al., 2001; Kim et al., 2006) as observed in the main natural estuary classifications, which never take into account the influence of human developments on sediment budget (Bowden, 1967; Fairbridge, 1980; Dalrymple et al., 1992). 
The Vilaine Estuary (Fig. 1), located on the French Atlantic coast, is a good example of a Holocene natural evolution strongly impacted by the human activity after construction of Arzal dam in 1970. The dam is situated at a distance of $8 \mathrm{~km}$ from the river mouth. The dam is responsible for estuarine infilling and major changes to the surrounding environment.

The aim of this study is to propose a hypothetical model based on the hydrodynamic modification and morpho-sedimentary development by analysing the natural estuarine evolution and the impact of human alteration to the natural system after 1970 . To achieve this, we collected data on river discharge, tidal currents, and wind and wave activities to further combine with photographic, bathymetric, topographic and sedimentary surveys. The comparison of these data with annual resolution will enable a precise understanding of relationships linking each hydrodynamic parameter to each other and their effects on sedimentary processes during the last 50 years in the estuary.

\section{Geographical setting}

The Vilaine Estuary is located in a particularly well and unique sheltered position along the French Atlantic coast (Fig. 1). The estuary opens on the southern coast of Brittany at the back of Vilaine Bay. The bay is protected behind a belt of highs (trending $\mathrm{N} 130^{\circ}$ ) consisting in the Quiberon peninsula, the Island Houat and Hoëdic, and the "Plateau du Four" rise, closed to the South by the headland of the Croisic (Fig. 1). The Vilaine Estuary drains a catchment of $10.530 \mathrm{~km}^{2}$ and collects $800 \mathrm{~mm} / \mathrm{yr}$ rainfall (typical of a temperate oceanic climate regime). Its infilling is less than 10,000 years old (Traini et al., 2013) and developed at the same time as most estuaries around the world (Pritchard, 1967; Russell, 1967; Boyd et al., 1992) when the last marine transgression slowed down ca. 6.000 years ago. Seawater flooded first the downstream part of the valley, which was rapidly filled up before the stabilization of the dynamic balance between river and marine inputs (Proust et al., 2001; Menier et al., 2010; Sorrel et al., 2010; Traini et al., 2013; Menier et al., 2014). Prior to the construction of the Arzal dam, tidal influence extended to a distance of $80 \mathrm{~km}$ onshore (MorzadecKerfourn, 1974).

This structural pattern of the Vilaine Estuary shows numerous areas of weakness promoting incision of depressions filled up by Quaternary sediments. The present day shape of the estuary correlates with three geomorphological parts tightly related to the geological heritage (Fig. 1).

- The inner part, 500 m wide, between the dam of Arzal and the haven of Tréhiguier, is incised into the prehercynian micaschists and orthogneisses through the Cadomian and Hercynian fault network;

- the central part, $2000 \mathrm{~m}$ wide, between the haven of Tréhiguier and the headlands of Penn-Lann (north) and Halguen (south),
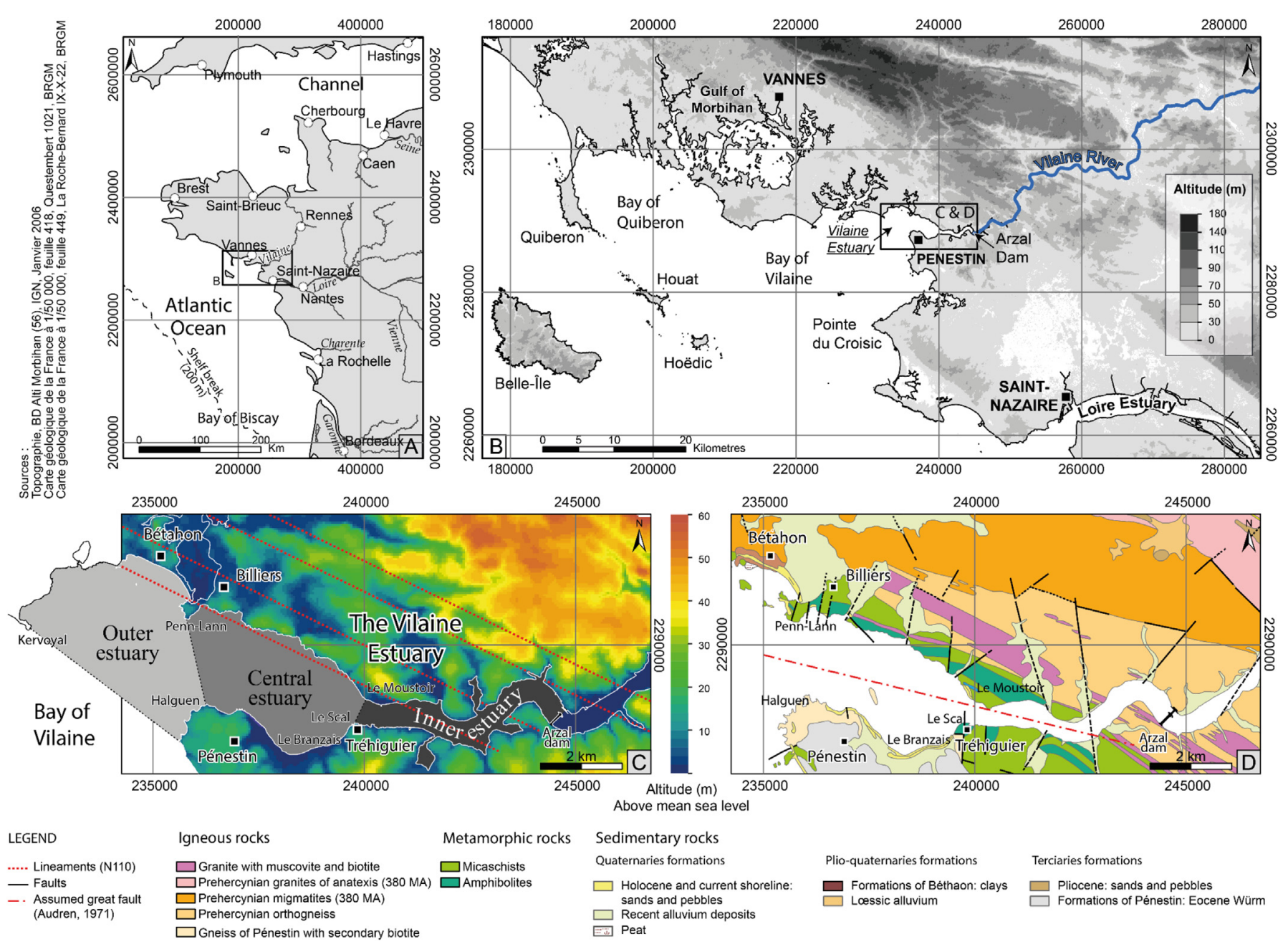

Fig. 1. Location map of the Vilaine Estuary. The figure shows the Vilaine Estuary location and its regional (A and B), geomorphological (C) and geological (D) contexts. 
with resistant micaschists and amphibolites rocks to the North, affected by a set of faults parallel to the southern branch of the South Armorican Shear Zone (trending N110 $-\mathrm{N} 130^{\circ}$ ), and covered by soft Tertiary and alterite sediments to the South;

- and the outer part, $4000 \mathrm{~m}$ wide, delimited by Penn-Lann, Halguen and Kervoyal headlands, is fringed by $10 \mathrm{~m}$ high eroded cliffs made up of amphibolites hard rocks (Traini et al., 2013).

\section{Data and method}

\subsection{Bathymetry}

The French Regional Facilities Office and French Naval Hydrographic and Oceanographic Service (SHOM) provided information on twelve (12) bathymetric surveys. We worked with surveys from 1960, 1977, 1983, 1992-2008. High resolution bathymetric surveys have been conducted intermittently with single beam echosounder and depending on the echo-sounder frequency; the sea-floor corresponds either to compact-mud $(33 \mathrm{kHz})$ or fluid mud (200 or $210 \mathrm{kHz}$ ).

\subsection{Topography}

\subsubsection{Digital terrain data}

Very high-resolution LIDAR (LIght Detection And Ranging) data provided by Institution d'Aménagement de la Vilaine (IAV), acquired on September, 2001 serve to extend bathymetric information to the upper part of the tidal-flat. The vertical and horizontal resolutions of the digital terrain model (DTM) are $10 \mathrm{~cm}$ and $50 \mathrm{~cm}$ respectively. A D-GPS was used for the topographic survey of the Branzais salt marsh in 2007.

\subsubsection{Aerial photography}

Five series of aerial photographs (1958, 1974, 1993, 2000 and 2004) provided by French National Geographic Institute (IGN), validated by field campaigns, aided the mapping of sedimentary environments (e.g. tidal-flats, salt-marshes, beach-barrier and cheniers).

\subsection{Water level and current patterns}

Information on sea-level was delivered by the French Naval Hydrographic and Oceanographic Service (SHOM) collecting tidal gauges data of Brest and Saint-Nazaire located respectively 175 and $30 \mathrm{~km}$ away from the Vilaine Estuary.

The French Naval Hydrographic and Oceanographic Service (SHOM) provided the model of tidal current distribution in the estuary and the French Meteorological service provided the data of wind speed and direction.

The Vilaine Management Institute (Institution d'Aménagement de la Vilaine) calculated discharge and recorded tide information from a tidal gauge located close to Arzal dam and supplied time series of ship-transits from 1990 to 2008.

Information on suspended load measured some tens of meters downstream the "Pointe du Scal" was found in Maillocheau (1980).

All the datasets used in this research and their corresponding sources are summarised in Table 1.

\section{Distribution of the estuarine sedimentary facies in space and time}

This section describes the distribution of present day estuarine sedimentary facies and an insight of their migration in space and time from a period starting before the construction of the dam in 1960-2008.

\subsection{Tidal-flats}

Tidal-flats of the Vilaine Estuary are of economic importance being the place of seafood culture with mussel (Mytilusedulis), clams (Tapes sp.) and cockles (Cerastoderma sp.). They represent c. $80 \%$ of the estuary area i.e. a surface of about 200 ha in the inner estuary, 650 ha in the central estuary (tidal-flats of Strado and Branzais) and 350 ha in the northern outer estuary (Fig. 2). The main channel, 60-920 m wide (from the inner to the outer parts), incises the tidal-flat. The slopes of the tidal flats are very low from $0.11 \%$ in the southern central estuary to $0.14 \%$ in the northern central estuary.

In order to show the clear distinction of tidal flats and main channel migration, we selected five (5) bathymetric survey results (Goubert and Menier, 2005) showing the most variations in patterns before and after the construction of the dam.

In plan-view, the growth of tidal flats and the shape of the main channel are closely linked as shown by the time series of the five (5) surveys (Figs. 3 and 4A-B), the growth of the tidal flat drastically reducing the channel wet-section (Fig. 3). Between 1960 and 2007, the reduction of channel wet section in the inner estuary is twice the reduction in the central and mid estuary. The wet-section is reduced from $34.5 \%$ to $53.9 \%$ in the inner estuary (Section 6-13) and $14.5 \%-25.7 \%$ (Section $1-5$ ) in the central and outer estuary.

In detail, the growth of tidal flats exhibits a step-like evolution as shown by the evolution of the $0 \mathrm{~m}$ isobaths (Fig. 4). The inner estuary displays a two-step migration. Between 1960 and 1992 the channel reduces its width (from 150-380 $\mathrm{m}$ to $100-210 \mathrm{~m}$ ) and channel meanders migrating landward (Fig. 4A). After 1992 the channel width remains stable but meanders migrate seaward

Table 1

Summary of datasets used in the study.

\begin{tabular}{|c|c|c|}
\hline Data & Data source & Year \\
\hline Bathymetry Survey & $\begin{array}{l}\text { French Regional Facilities Office and French Naval Hydrographic and } \\
\text { Oceanographic Service (SHOM) }\end{array}$ & $\begin{array}{l}\text { 1960, 1983, 1989, 1992, 1994, 1995, 1998, } \\
\text { 2001, 2003, 2005, 2007, } 2008\end{array}$ \\
\hline Aerial Photography & French National Geographic Institute (IGN) & $1958,1974,1993,2000,2004$ \\
\hline LiDAR & Institution d'Aménagement de la Vilaine (IAV) & 2001 \\
\hline Topography & University of South Brittany (UBS); Institution d'Aménagement de la Vilaine (IAV) & 2007 \\
\hline Wind Data & Latteux, 2005; Pirazzoli et al., 2004; & 1951-1979 \\
\hline Wave/Tidal Data & Institution d'Aménagement de la Vilaine (IAV); Latteux, 2005; Tessier, 2006 & $1979-2000$ \\
\hline Suspended Load & French Central Hydraulic Laboratory (LCHF); Maillocheau 1980 & 1960 \\
\hline River Discharge & Institution d'Aménagement de la Vilaine (IAV); Maillocheau, 1980 & $1934-2008$ \\
\hline North Atlantic Oscillation (NAO) & The National Center for Atmospheric Research; Hurrell and Deser, 2009 & $1934-2008$ \\
\hline Sea Level Change & French Naval Hydrographic and Oceanographic Service (SHOM) & $1970-2009$ \\
\hline
\end{tabular}




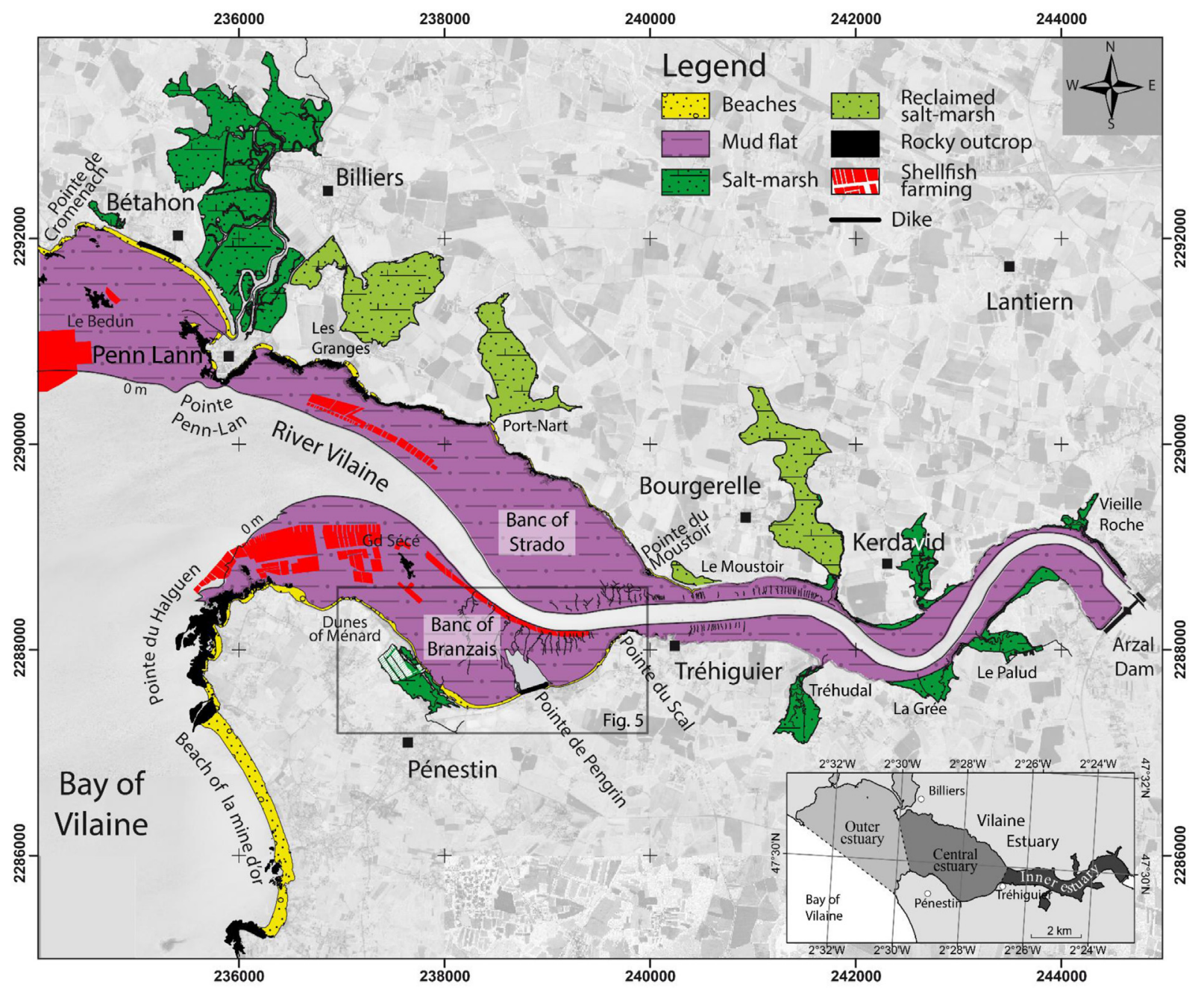

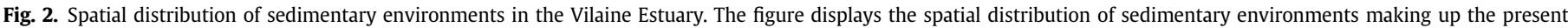

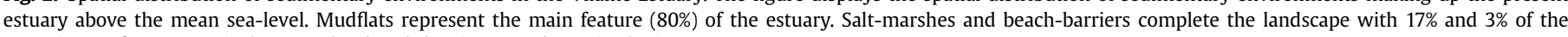
estuarine surface respectively. Note that beach-barriers are absent in the inner estuary.

(Fig. 4A). Similarly, the Strado tidal flat has grown in a seaward direction in the central estuary between 1960 and 1992 (up to $470 \mathrm{~m}$ ) (Fig. 4B), and sets then up seaward in the outer estuary from 1992 to 2007 (360 m). The Branzais tidal-flat was limited to the central estuary but stepped landward between 1960 and 1992 (up to $240 \mathrm{~m}$ ), and then seaward between 1992 and 2007 (200 m).

A similar landward then seaward evolution is observed when looking at sedimentation rates. From 1960 to 1983, up to $8 \mathrm{~m}$ of sediment accumulated in the inner estuary (c. $35 \mathrm{~cm} /$ year of sedimentation rate). The depocenter migrates upstream from 1983 to 1992 (arrow 1 in Fig. 4C) accumulating up to 5 m-thick sediments (c. $55 \mathrm{~cm} /$ year of sedimentation rate) and then downstream from 1992 to 2007 (arrow 2 in Fig. 4C) piling up to $5 \mathrm{~m}$ of sediment (c. $55 \mathrm{~cm} /$ year of sedimentation rate) (Goubert and Menier, 2005).

\subsection{Salt-marshes}

Aerial photographs show 11 distinct salt-marshes in lowlands connected to the main fluvial valley (Fig. 2). They represent $17 \%$ of the estuarine surface and display a flat topography. Their altitude differs from place to place ranging from 1.9 to $3.1 \mathrm{~m}$ above mean sea-level. In the inner estuary, salt marshes are in contact with tidal-flats through a $0.50 \mathrm{~m}$ to $1 \mathrm{~m}$-high micro-cliff. In the outer and central estuary, salt-marshes are located at the back of beachbarriers. Some salt marshes are reclaimed for agriculture (Fig. 2); others in connection with seawater are characterised by halophytic vegetation belts controlled by periodic tidal flooding.

Analyses of time-series photographs reveal a landward retreat of the boundary between tidal-flat and salt marshes in the inner estuary between 1971 and 2004. However, the two riversides are asymmetrically affected by erosion. Salt marshes of the convex riverside retreated by $8-30 \mathrm{~m}$ whilst salts marshes of the concave riverside retreated by 5-20 m between 1971 and 2004 .

\subsection{Beach-barriers}

Beach-barriers or cheniers represent about $3 \%$ of the estuarine surface namely. $17 \mathrm{~km}$ of discontinuous beaches or $60 \%$ of the estuarine coast, which is $28 \mathrm{~km}$ in total (Fig. 2). Beach barriers are only present in the southern and northern sections of the central estuary (fringing the tidal flat of Branzais and of the Strado), and in the northern part of the outer estuary (closing salt marshes of Bétahon) (Fig. 2). These beaches display morphologies indicating active sediment transport. The northern beach of the outer-estuary ends with a sandy-hook at the outlet of a tidal creek and beaches of the outer estuary and of the southern central estuary display 


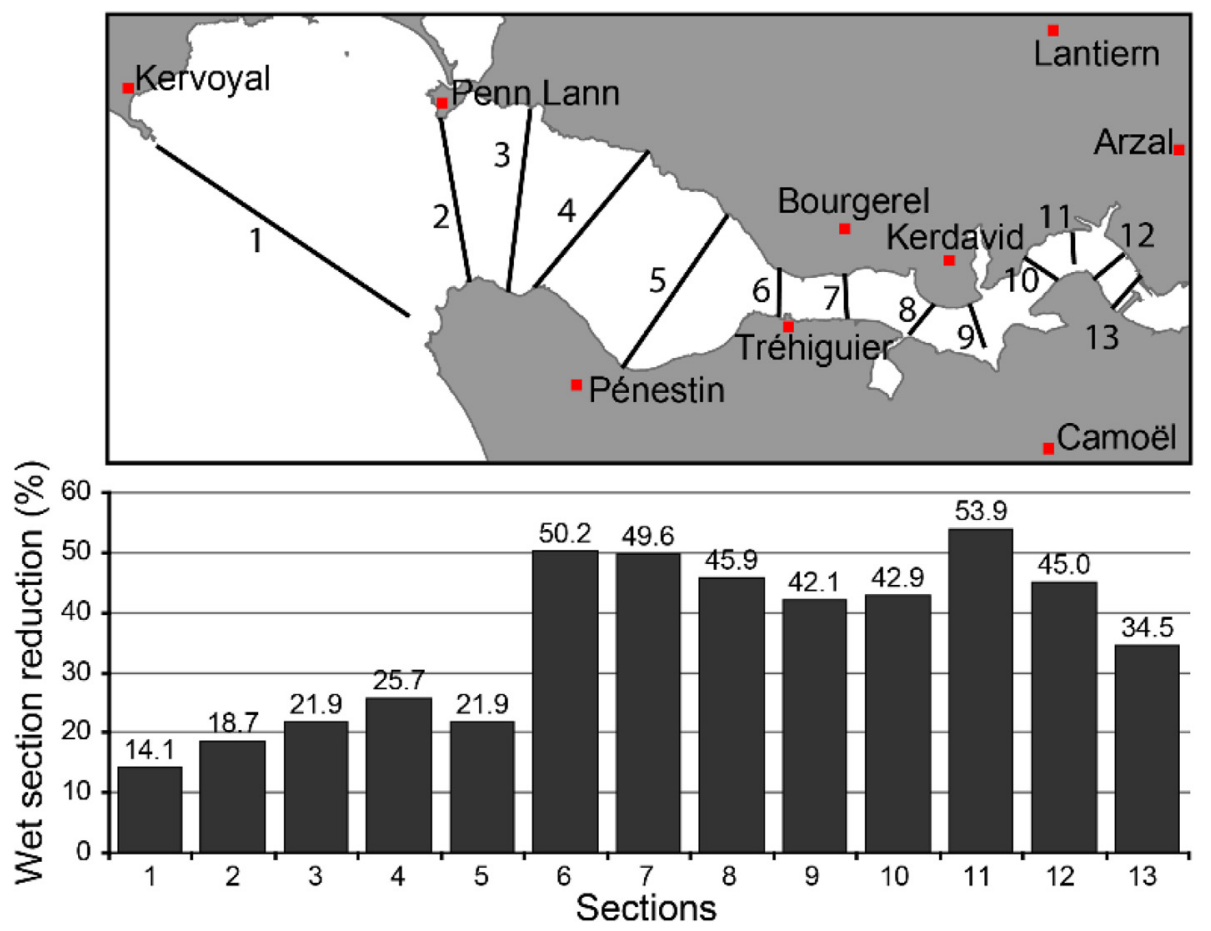

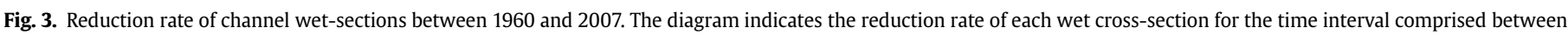
1960 and 2007. Wet cross-sections are numerated and reported on the map. Reduction rates of wet cross-section are expressed as percentages.

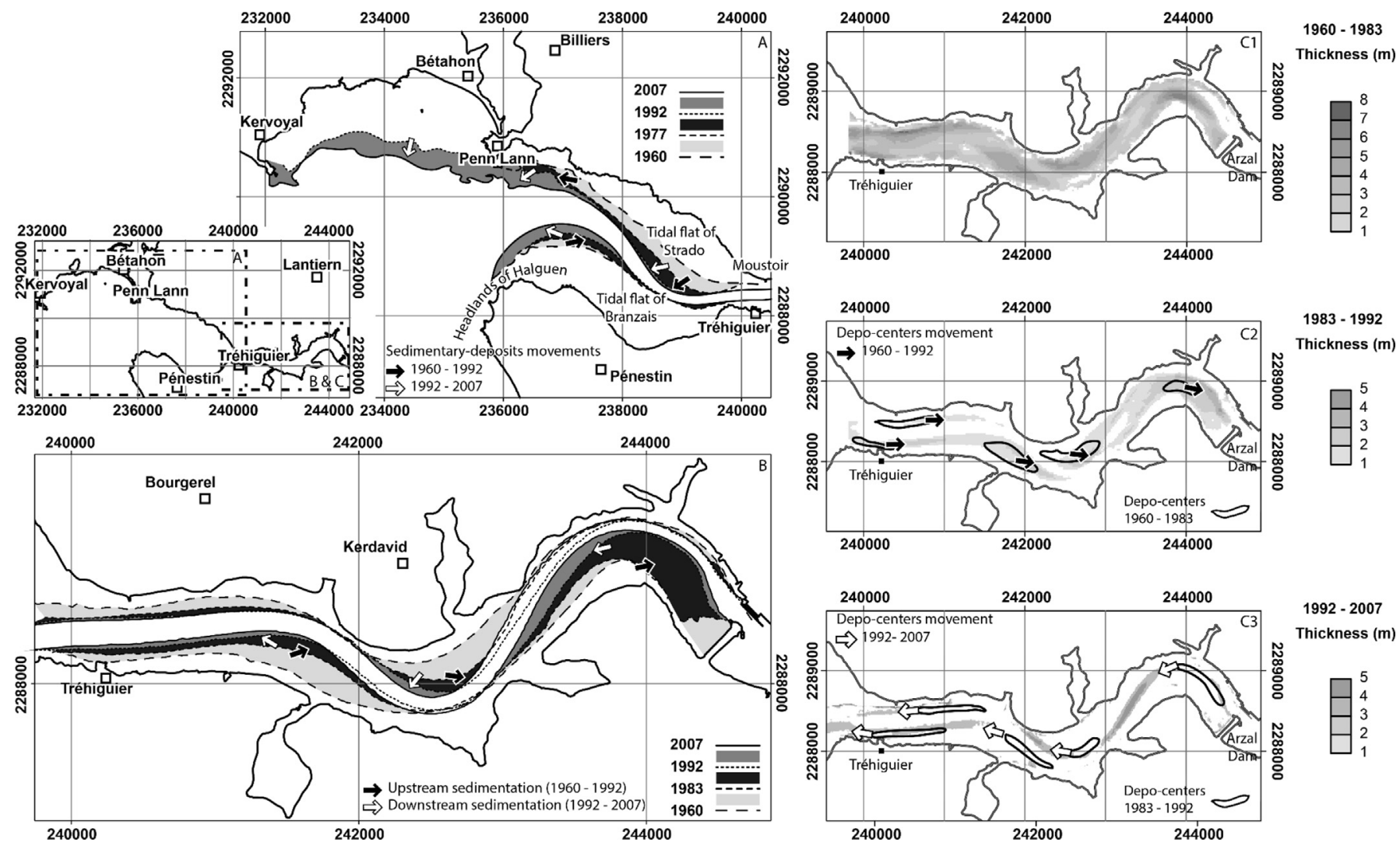

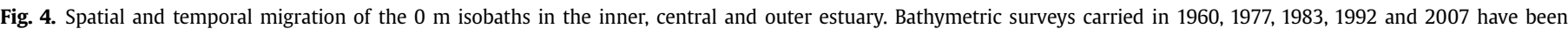

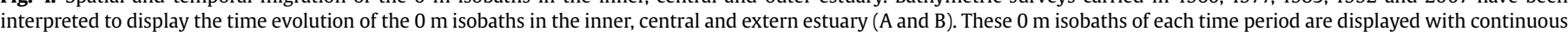

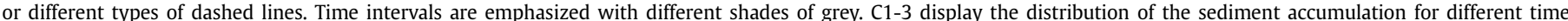

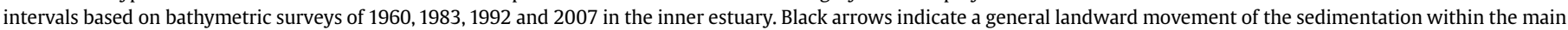
channel (time period 1960-1992). White arrows indicate a seaward orientation of the sediment accumulation for the time period $1992-2007$. 
coalescent "crescent beaches". This sandy material encroaches on salt marshes as storm wash-over fans or cheniers.

The study of nautical chart (SHOM), aerial photographs and results of field campaigns shows fairly stable beaches except those located in the southern central estuary. This sector records particularly active long-shore (up to $15 \mathrm{~m}$ per year during the last decade) and cross-shore movements of sedimentary bodies (Fig. 5). The construction of the dike of Branzais has stopped the coastal retreat $(100 \mathrm{~m})$, which occurred before 1958 (Fig. 5A). The topographic survey of 2007 compared with the nautical chart of 1820 and aerial photographs of 1958 and 1993 shows that parts of the "Dunes of Ménard" sand ridges (Fig. 5B) are stabilised. However, since 2007, coastal retreat is very active in this area.

\section{Natural controls on the morpho-sedimentary evolution of the Vilaine Estuary}

River discharge, waves and tides are the three main hydrodynamic factors that control the shape and sediment distribution in estuaries (Boyd et al., 1992; Dalrymple et al., 1992). These parameters are influenced by the climate regime. The Vilaine Estuary is subject to a temperate oceanic climate regime.

\subsection{Tides}

Tides are semi diurnal in the Vilaine Estuary. The mean amplitude oscillates between $4.75 \mathrm{~m}$ during mean spring tides and $2.25 \mathrm{~m}$ during mean neap tides. The maximal amplitude during

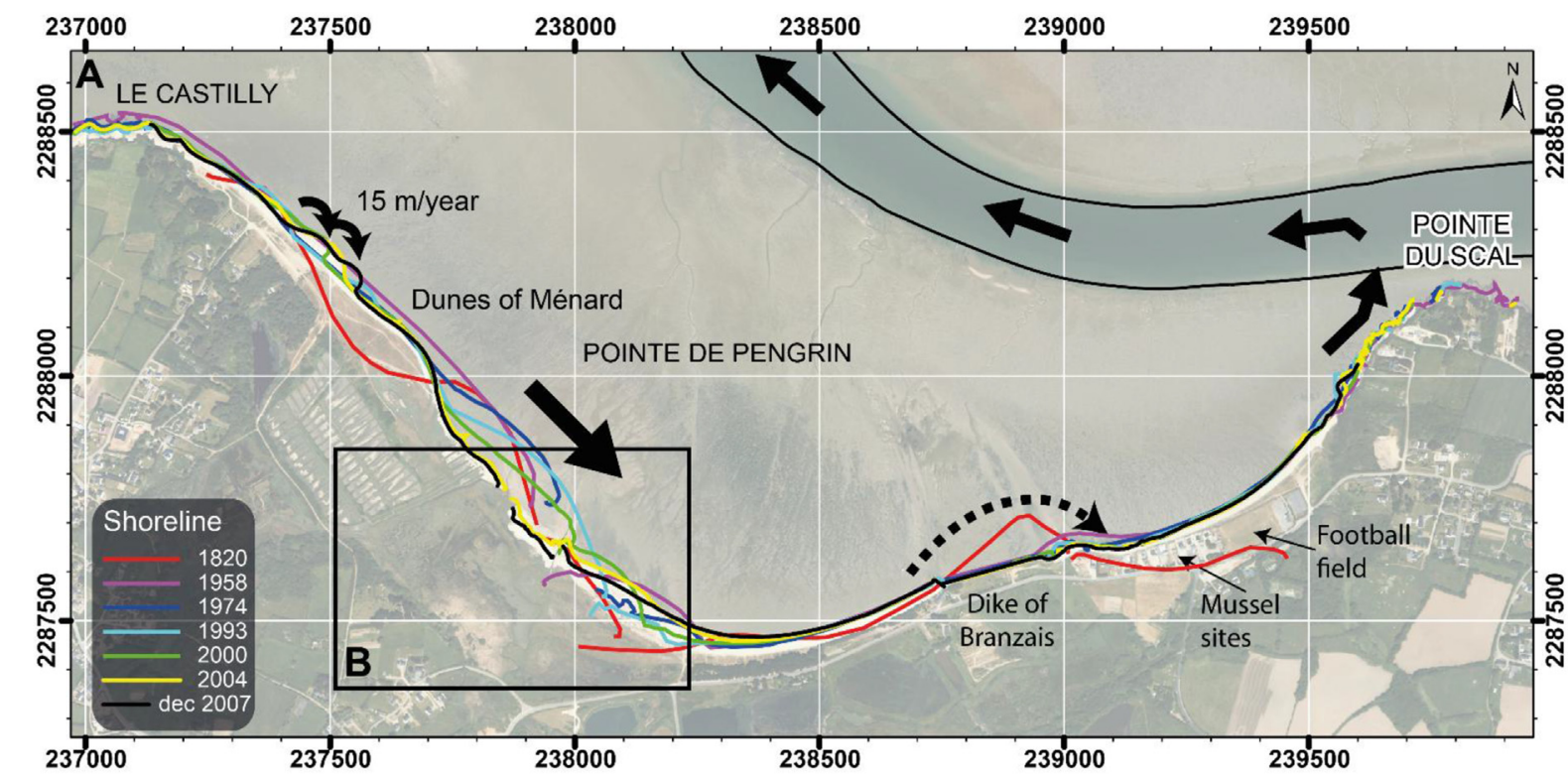

\section{:
జ.
సิ}
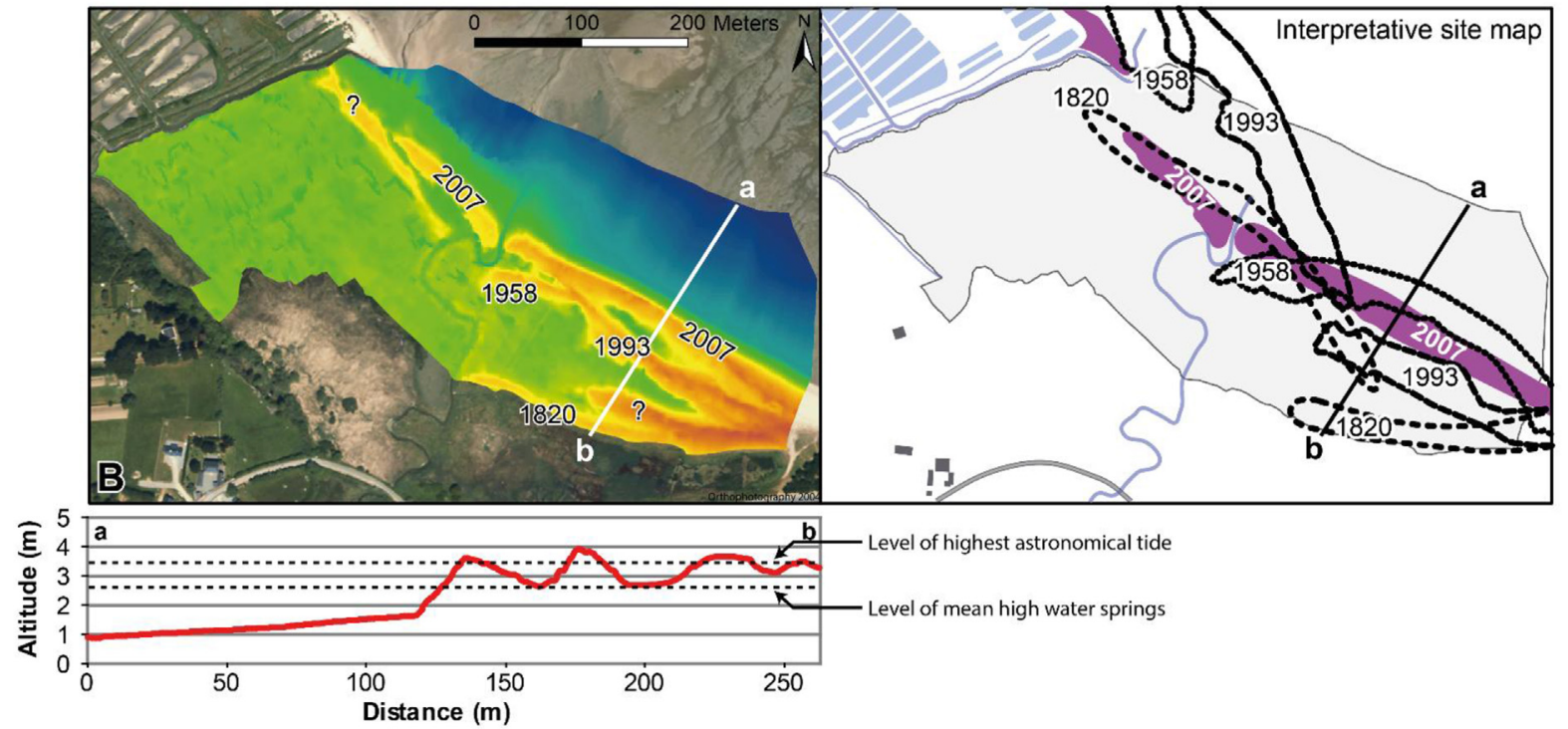

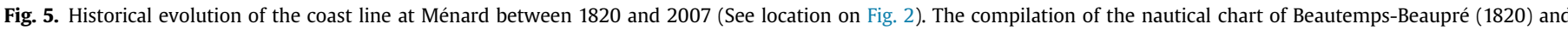

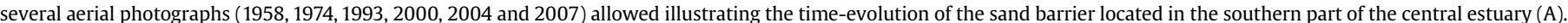

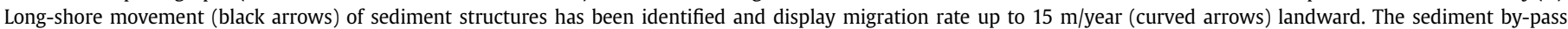

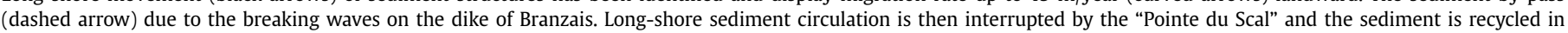

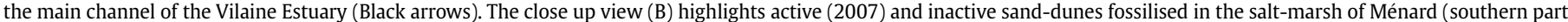

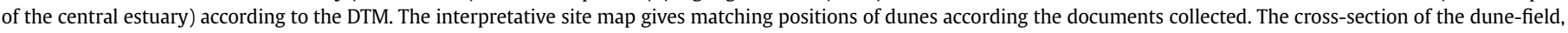
related to the characteristic tidal levels, indicates a sediment accumulation under the combined action of tides and waves. 
exceptional spring tide reaches $6.39 \mathrm{~m}$. Estimates of the current intensities, which do not take into account the river discharge, are expressed along five points from the outer to the inner estuarine parts. Despite that the model does not show any amplitude distortion, the shape of the current-velocity, the current-time asymmetry as well as the estuarine funnel shape suggest an hyper synchronous behaviour of the estuary (Salomon and Allen, 1983) where convergence effects encompasses friction damping.

\subsection{Wind and waves}

The wind data-set (1951-1980) shows that winds come mainly from the West for 340 out of 1000 observations (Latteux, 2005). Between 1975 and 1997 wind strengths from West and South sectors increased respectively of $26.68 \pm 7.76$ and $22.53 \pm 7.25 \mathrm{~cm} /$ s/yr (Pirazzoli et al., 2004).

Wave height simulations at $\mathrm{N} 46^{\circ} 54^{\prime}-\mathrm{W} 4^{\circ} 12^{\prime}(85 \mathrm{~km}$, southwest of Belle-Ile Island) from 1979 to 2000 (Tessier, 2006) and at $\mathrm{N} 46^{\circ} 52^{\prime} 30^{\prime \prime}-\mathrm{W} 3^{\circ} 20^{\prime} 00^{\prime \prime}$ (50 km, south-southwest of Belle-Ile Island) from 1979 to 1998 (Latteux, 2005) show a strong attenuation of the oceanic waves in the Bay of Vilaine due to the sheltering highs. Waves are only 1 or $2 \mathrm{~m}$-high in the bay of Vilaine when they are $4-5 \mathrm{~m}$-high outside the bay (Tessier, 2006). Model produced by Latteux (2005) for maximum wind and wave conditions with a return period of $1 \%$ of the time indicates that residual waves reaching the river mouth are in average of $1.35 \mathrm{~m}$ for western storms and of $1.50 \mathrm{~m}$ for WSW storms. Fair weather waves rarely exceed $0.5 \mathrm{~m}$ in the bay due to the very limited fetch.

\subsection{Suspended load}

The turbidity zone in estuaries is a typical feature controlled by both tidal currents and river discharge patterns. A modification of the suspended load often reflects a change in hydrodynamic parameters. Measurements of suspended load in the Vilaine Estuary were rare before the construction of the dam. The French Central Hydraulic Laboratory (LCHF) carried out some measurements by low river discharge (early 1960's). Suspended particulate matter (SPM) concentration in the estuary varied from $50 \mathrm{mg} / \mathrm{l}, 15 \mathrm{~km}$ upstream of the present day position of the dam, to $5000 \mathrm{mg} / \mathrm{l}$, at the present day position of the dam, and above $100 \mathrm{mg} / \mathrm{l}$ at the river-mouth (Merceron, 1985).

\subsection{Sea-level change}

The Vilaine Estuary is located less than $200 \mathrm{~km}$ from Brest and Saint Nazaire tidal gauges. Sea-level records of the Brest gauge station display a rise of sea-level of c.100 mm between 1970, when the dam started to operate, and 2009 (SHOM). Saint-Nazaire time series are shorter (1965-1988) but the annual mean sea-level rise is very close to the time series in Brest. So, sea-level rise, not monitored in the Vilaine Estuary, should be very likely similar to this of Brest. Several studies indicate that storm surges decreased these last years on the French Atlantic front (Pirazzoli, 2000; Pirazzoli et al., 2004). The effects of sea-level rise could therefore be felt even stronger.

\section{Dam effects on the morpho-sedimentary evolution of the Vilaine Estuary}

\subsection{Tidal currents}

Table 2 shows current velocities measured before the construction of the dam when the tidal oscillation propagated $70 \mathrm{~km}$ in the upstream direction. Since the construction, oscillating water
Table 2

Evolution of current velocities at flood and ebb tide before and after the dam construction (modified after Maillocheau, 1980).

\begin{tabular}{clllr}
\hline Tidal characteristics & Tidal amplitude & Before dam & After dam & Trend \\
\hline Ebb max. current & Low & 0.73 & 0.75 & $3 \%$ \\
velocities (m/s) & Medium & 1.06 & 0.76 & $-28 \%$ \\
& High & 0.85 & 0.90 & $6 \%$ \\
Food max.current & Low & 0.75 & 0.38 & $-49 \%$ \\
velocities (m/s) & Medium & 0.96 & 0.33 & $-66 \%$ \\
& High & 0.90 & 0.58 & $-36 \%$ \\
Time ratio ebb/flood & Low & 1.10 & 1.80 & $64 \%$ \\
& Medium & 1.20 & 1.60 & $33 \%$ \\
& High & 1.30 & 1.30 & $0 \%$ \\
\hline
\end{tabular}

volume was reduced by $43 \%$ during spring tide $\left(81.10^{6} \mathrm{~m}^{3}\right.$ before, $46.10^{6} \mathrm{~m}^{3}$ after construction) (Maillocheau, 1980; Merceron, 1985). The maximum ebb current velocities decreased up to $30 \%$ for medium tidal amplitude at four kilometres downstream the dam (Tréhiguier, Fig. 1) (Maillocheau, 1980) when maximum flood current amplitude decreased up to $36 \%-66 \%$ (Table 2). The ebb and flood currents time ratio increased up to 30\%-60\%. Therefore the management of the dam seems responsible for a general decrease of tidal-currents energy reinforcing their asymmetry. However, these results are sensitive to the river flow, which varies during the measurement time period and have not been taken into account.

\subsection{River discharge}

River discharge has been managed since the construction of the dam, to promote the navigation on the upstream part of the river, to protect the marshes of Redon during conjunctions between river flood and spring tides, and to maintain a fair water level for drinking water production. The management of water discharge is run according to fresh water inputs, tide levels and human needs. The dam artificially releases water during falling or low tide, instead of high tide, to protect the fresh water reservoir against salt water.

When plotting together water-releases and tidal oscillations through time in diagrams selected for three different flow regimes, the impact of the dam management on the water flow at the back and at the front of the dam can be illustrated (Fig. 6).

During river-flood regime $\left(>250 \mathrm{~m}^{3} \mathrm{~s}^{-1}\right)$, freshwater is released by the dam with interruptions of $3-5 \mathrm{~h}$ at high-tide. These important releases (from 0 to $800 \mathrm{~m}^{3} \mathrm{~s}^{-1}$ ) change the upstream flow-rate of about $100 \mathrm{~m}^{3} \mathrm{~s}^{-1}$ (at Rieux, Fig. 6). The tidal ebb-phase is particularly extended but the water level stays $3 \mathrm{~m}$ above the position of the lowest waters (Low tide Low Waters, LLW).

During mean river-flow $\left(100-250 \mathrm{~m}^{3} \mathrm{~s}^{-1}\right)$, the fresh-water released close to the natural conditions still impacts the discharge upstream of the dam. The discharge is regulated by the gates until $4.5 \mathrm{~m}$ above LLW and by the flaps below $4.5 \mathrm{~m}$ LLW. The flood-phase is slightly longer than the ebb phase possibly because of sea wind activity.

During slack river-flow $\left(10-100 \mathrm{~m}^{3} \mathrm{~s}^{-1}\right)$, the dam is closed at high tide. The small releases due to the technical functioning of the dam (lock, fish-way and salt-water pump) represent half of the "natural" discharge. River discharge at Rieux displays a strong oscillating rate, set between less than $10 \mathrm{~m}^{3} \mathrm{~s}^{-1}$ and $60 \mathrm{~m}^{3} \mathrm{~s}^{-1}$. The dam is closed below $10 \mathrm{~m}^{3} \mathrm{~s}^{-1}$.

These three examples show that water-releases are irregular for any river flow or tidal conditions. They strongly impact the freshwater supply to the estuary and reinforce ebb tidal currents during river-flood period. 
a) Flood regime condition

Data: IAV
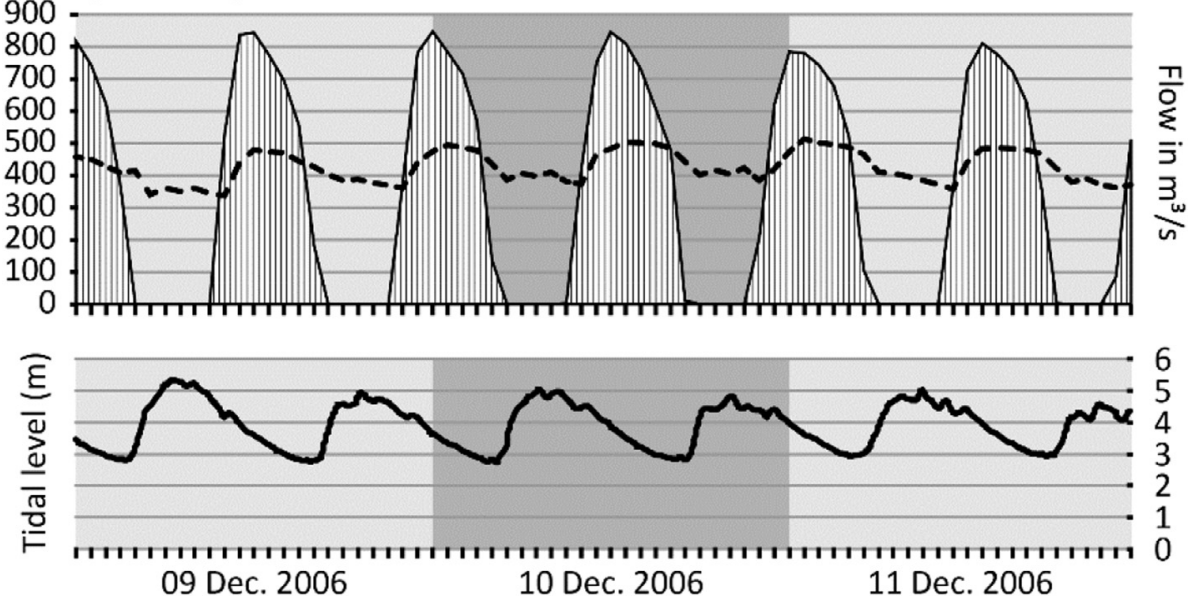

b) Mean flow condition
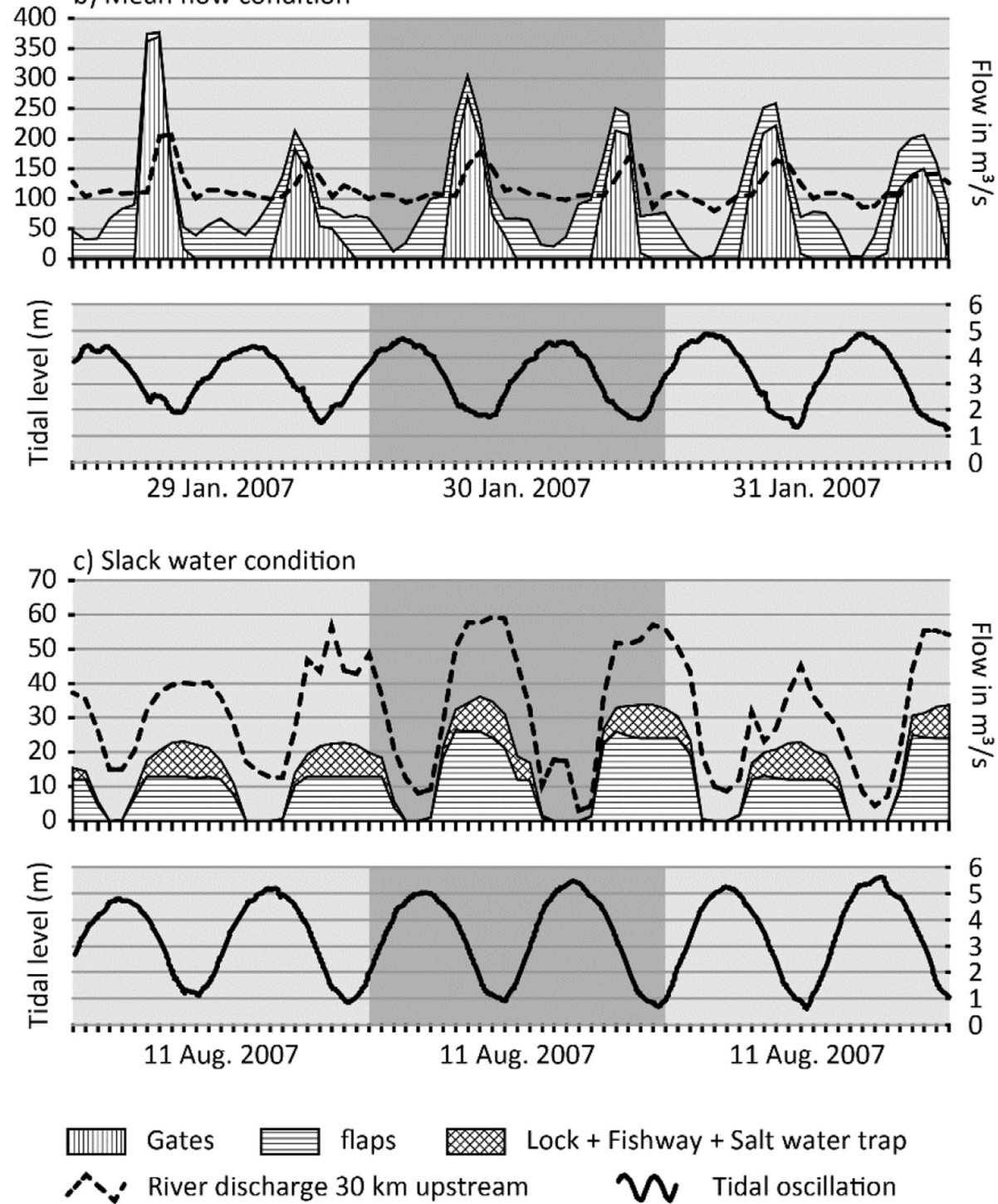

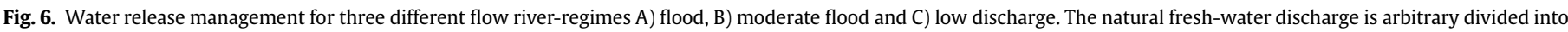

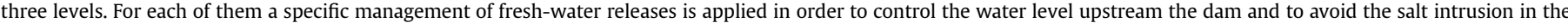

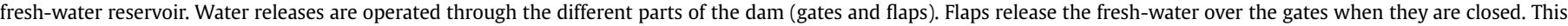

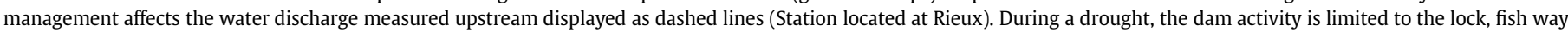
and salt water pump. Gates and flaps are closed. 


\subsection{Suspended load}

In all circumstances, measurements of suspended load had a maximum at the bottom, at low tide during spring tide (Maillocheau, 1980; Merceron, 1985).

Just after the construction there is two maximum values recorded by two different authors: a concentration of $497 \mathrm{mg} / \mathrm{l}$ is recorded close to the place of the $5000 \mathrm{mg} / \mathrm{l}$, in the inner estuary (Merceron, 1985) and $1473 \mathrm{mg} / \mathrm{l}$ at the western part of the central estuary (Maillocheau, 1980). Therefore the maximum turbidity, at low tide, migrated from the place of the Dam (before construction) to the central part (after construction), we estimated that the maximum turbidity decreased from 5000 to $1473 \mathrm{mg} / \mathrm{l}$.

For records performed all along the tidal cycles, SPM values decreased to $10 \%$ during neap tide, $20 \%$ in spring tide and $11 \%$ for medium tide period when compared to the pre-dam conditions (Maillocheau, 1980). During high tide, the upstream limit of the maximum turbidity zone is located either at the narrowing between the central and internal estuary (Maillocheau, 1980) or slightly landward, $2 \mathrm{~km}$ downstream the present position of the dam (Merceron, 1985). Thus, the construction of the dam reduced the extent and the concentration of the maximum turbidity zone (Latteux, 2005).

\subsection{Ship transits}

The information on ship transits is relevant for this study due to its potential erosional effect on river-banks caused by the generation of wake waves. Indeed, leisure and fishing activities drastically increased since the construction of the dam (unpublished data from the IAV). Two thirds of the ship transits occur during summer time and particularly during ebb slack waters (due to water releases management which prevent any salt water intrusion in the water reservoir). Leisure-, trade- and fishing-boats passing through the lock of the dam represent up to 16,000 transits per year. This number does not take into account boat-movements for fishing activity downstream the dam. This transit may have an effect on the surroundings.

\section{Discussion}

\subsection{Controlling factors of the morpho-sedimentary evolution of the Vilaine Estuary}

Climatic changes and anthropogenic actions are the most important parameters steering the sedimentology of the Vilaine Estuary. Fig. 7 summaries the effect of natural and human controls on the historical morphological evolution of the Vilaine Estuary, before and after the construction of the dam.

\subsubsection{Natural controls}

The morphology of estuaries controls accommodation space and determines wave and current pathways. River discharge, windwaves and tides, modulated by climate change, are the three main hydrodynamic parameters acting in an estuary driving patterns and movements of sediment bodies (Short, 1999; Green and MacDonald, 2001; Masselink and Hughes, 2003).

Associated with tidal-currents and sediment load, waves refracted on the headlands of Penn-Lann and Halguen win now the sediment on the tidal flat. Breaking-waves carry coarse particles in a landward direction in the swash zone while back-currents take back the finest part in a seaward direction, which is then deposited on the tidal flat during high-tide slack waters. This results in contiguous and synchronous deposition of cheniers and sand beaches with crescent figures on the top of salt-marshes and mudflat in the lower part of the tidal flats.

The altitude of the crests of the wave-generated sand-bodies fit to the high-tide levels (Fig. 5B). In 1958, 1993 and 2007 these sand bodies showed characteristic erosion features followed by sedimentation pointing to an alternation of accretion/erosion phases (Fig. 5). At a larger scale, by comparing time series of the coastline morphology, a general net accretion is observed until the snapshot of 1974 (Fig. 5A). Since that time, local erosion and change in hydrodynamics shifted the sediment from the northwest (Dunes of Ménard) to the southeast. The origin of this sediment transfer can be explained by the increase of southerlies and westerlies between 1975 and 1997 (Pirazzoli et al., 2004). These two wind directions take advantage of a long fetch and generate the highest waves in the bay and at the entrance of the estuary (Fig. 1). Finally, this study shows that despite relatively sheltered conditions; wave, tide and sea-level rise control the position of beach-barriers and fine sediment transfer into the estuary.

Interpreting the progradation and retrogradation of sand-ridges (Fig. 5B), the one dated around 1993 seems to be the last recent episode of a retrogradation of the shore line. This event involves relative stronger hydro-dynamic activity. Gathering information of two studies (Bouligand and Pirazzoli, 1999) and (Phillips and Crisp, 2010), 1993-1994 characterise pivotal years of high wave activity. The first study conducted at Brest (France) shows the frequency of extreme storm surges has increased during the period 1953-1994. The second study, conducted in the Bristol Channel and Severn Estuary (England), indicates decreasing trends of sea-level maximum and increasing trends of minimum sea-level between 1993 and 2007 for extreme NAO index. Storm surge and sea-level maximum was recorded by these studies around 1993; therefore we infer that those last events (storm surge and sea-level maximum) are thus possibly recorded in southern part of the central estuary with the fossilised sand-ridge of 1993 marking the last recent episode of a retrogradation of the shore line (Fig. 5B).

Coastal erosion of the southern central part of the estuary seems to be linked with parameters such as wave, storm surge and sealevel which are dependent of climate conditions.

\subsubsection{Human impact}

The construction of the dam is the main human impact on the morpho-sedimentary evolution of the Vilaine Estuary. The dam building increased coastal erosion, decreased the tidal prism and tidal current energy, and changed fresh water releases and wake waves due to the leisure-ship traffic.

The position of the dam constrains the present maximum turbidity to the central estuary. The reduction of the tidal prism and release of freshwater from the dam performed during ebb tide lead to a reduction of current velocity and an increase of ebb tide duration (Table 2). This contributes to the observed decrease of the maximum turbidity from $5000 \mathrm{mg} / \mathrm{l}$ before to $497 \mathrm{mg} / \mathrm{l}$ after the construction of the dam in the inner estuary at low tide during spring-tide (Merceron, 1985).

The general decrease of current velocities enhances also settling processes of fine particles on mudflats. The tidal flat extends leading to a reduction of the channel wet-cross-section (Figs. 3, 4 and 7).

In the other hand, despite high sedimentation rates in the main channel and in the lower part of the tidal flat, salt-marsh edges are eroded out in the central and inner estuary. This erosion cannot be explained by the lack of sediment. The recent rise in sea-level together with the position of the dam close to the river mouth $(8 \mathrm{~km})$ stops the landward propagation of the flood tidal-wave and generates an supplementary tidal surge, as observed for instance in the Keum Estuary (Kim et al., 2006) or in the Ems Estuary (max. $29 \mathrm{~cm})$ (Krebs, 2010). Thus the elevation of the sea-level 

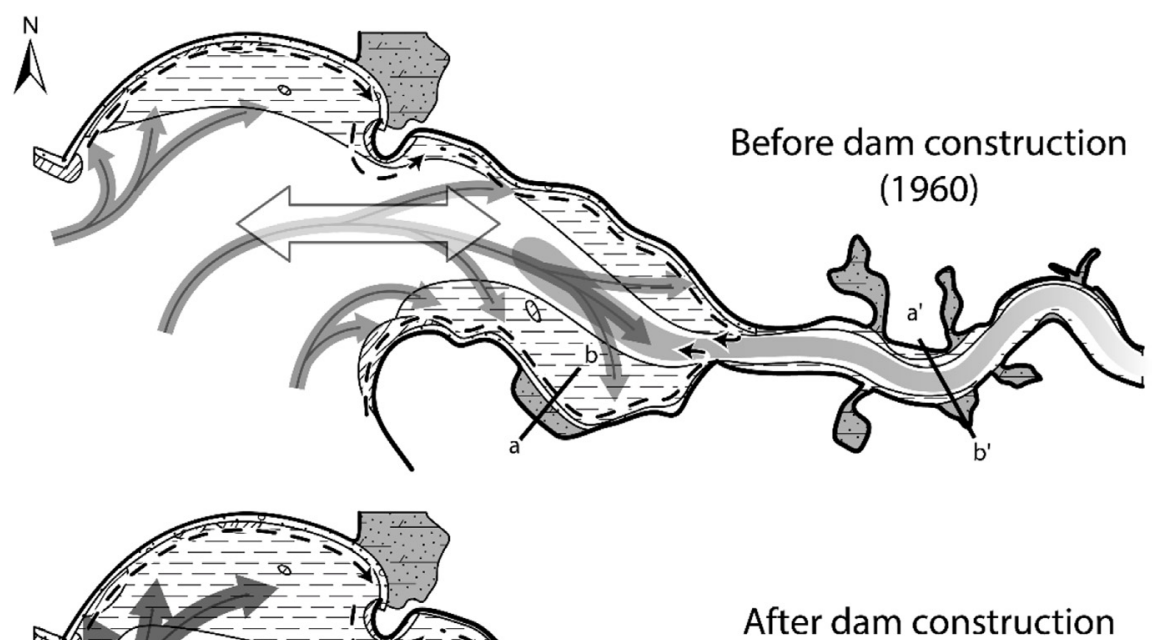
(2007)
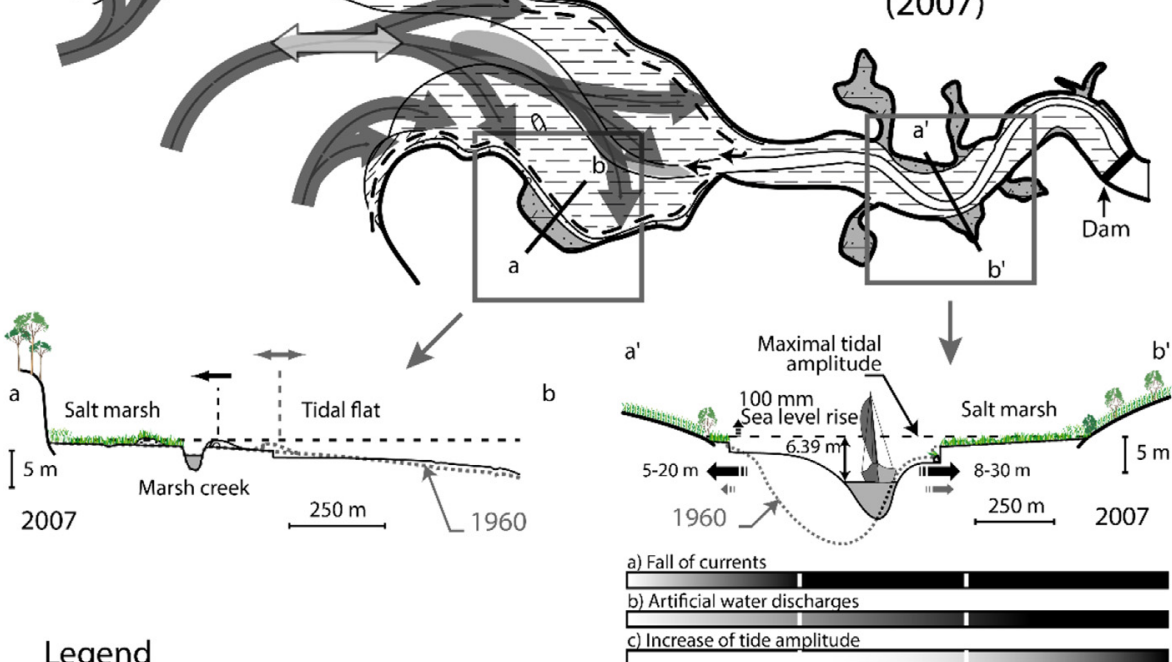

Legend
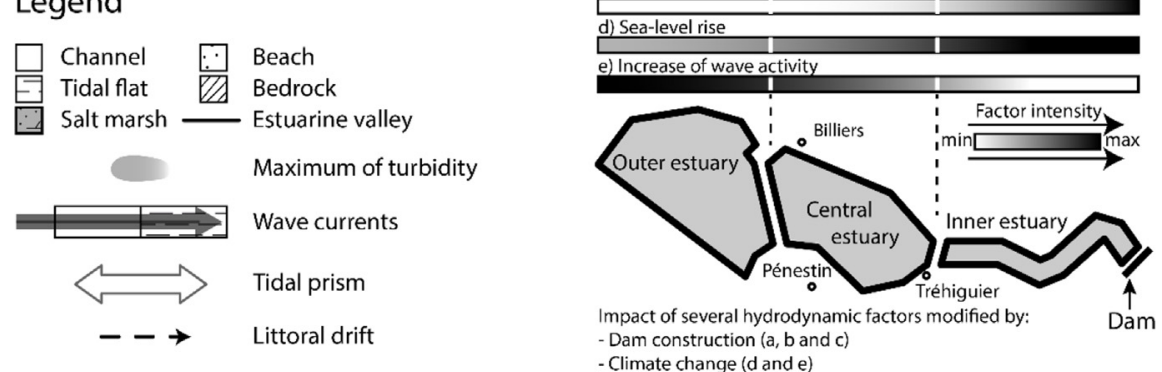

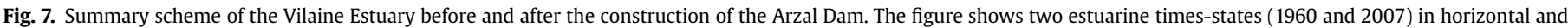

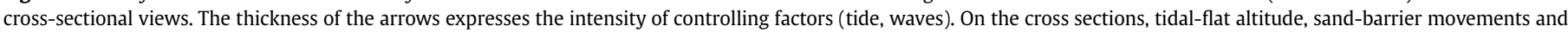

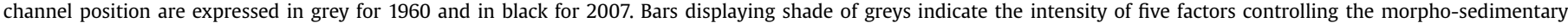

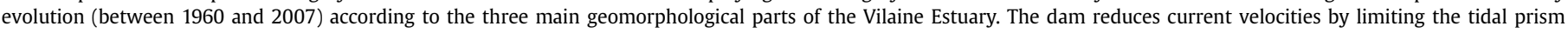

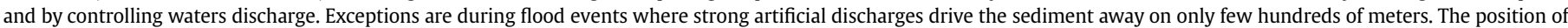

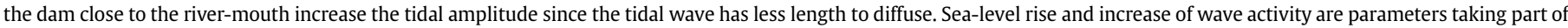
the hydro sedimentary functioning of the estuary and are correlated to the climate change.

concomitant probably with wake waves resulting of the ship traffic weakens the marsh and causes its erosion. Therefore, the erosion recorded in the inner estuary is then more the consequence of the combined adaptation to a new water base level and wake-wave process than a lack of sediment.

Due to its geology and structure, the Vilaine valley can be compared to a ria system (Traini et al., 2013). In such a context, the $100 \mathrm{~mm}$ of rise of sea-level since 1970 should have increased the current velocities in the estuary (Bird, 1993; Pethick, 1993). However, this is not the case because, at the same time, the tidal prism has been reduced up to $43 \%$ with the construction of the dam. The estuarine channel enlarged by increasing salt-marsh erosion and the channel sections did not deepen but have been filled up with sediment.

\subsection{A sediment circulation cell}

Along the study period, the "natural" evolution of the Vilaine Estuary sediment-cell shows, in the central and outer estuary, a landward alongshore sediment transport dominated by wave 
action. The northern coast of the outer and central estuary receives primary waves refracted by the tidal flat. The lateral shift of the sand spit of Bétahon, adjacent to the rocky headland of Penn-Lann, and the pocket beaches with superimposed eastward oriented sand waves point to a landward and eastward littoral drift. Similar observations are made for the southern coast of the central estuary. This coastal area, sheltered by headlands of Halguen, receives only refracted waves. The presence of a longshore sand drift up to $15 \mathrm{~m} /$ yr close to the Dunes of Ménard as well as crescent-shaped sandbodies on the downstream side of the southern beaches point to a perpendicular to oblique wave incidence (Fig. 5) (Short, 1999). Thus, the Vilaine Estuary traps sandy particles coming from two, southern and northern, littoral drifts (Fig. 7) which are either reworked or spread over the salt-marshes as shelly-sand wash-over fans and/ or cheniers.

The southern and northern littoral drifts meet at the narrow of Tréhiguier which bounds the inner and the central estuary (Figs. 1 and 7). The lack of sand banks along the river-side of the inner estuary suggests that river discharge combined with tidal-currents blow the sand out of this inner part of the estuary. The finest particles settle during slack water of high tide in the inner estuary and contribute to the expansion of the mudflat. The expelled sandy material at ebb tides builds up sand-rich low angle subtidal lobes in the outer estuary (the "subaqueous delta" described by Guilcher in 1958). The sand from time to time is picked up by storm wave action and reintroduced in the Vilaine Estuary. Fine-grained particles originating from the bay or provided by salt-marshes erosion are reintroduced by flood tides and wave action in the system, settling on the middle and lower parts of the mudflat contributing to its expansion. Most eroded sediments participate to the sediment circulation in a closed loop.

The Bay of Vilaine at the outlet of the estuary is a sheltered trap of sediment and an external source of fine-grained material for the estuary. The bay is largely fed by the Loire River estuary which releases $0.610^{6} \mathrm{t} / \mathrm{yr}$ of suspended load (the second largest of the French Atlantic coast) (Joulanneau et al., 1999), by strong south westerlies. This illustrates again that the increase of wave activity is a factor of further sediment accumulation in the Vilaine Estuary.

\subsection{A two-step infilling scenario}

Since the beginning of the marine transgression in the estuary 10,500 years ago (Traini et al., 2013) sediments onlap the basement in a landward direction. The large wet cross-section of the main channel allowed the dominance of flood tidal currents leading to a landward sediment deposition. After the construction of the dam until the early 1990 , the channel wet-cross-section reduced rapidly due to the fall of tidal currents and related accumulation of fine particles on mudflats. During this lap time of 20 years, sediment accumulation was still oriented in an upstream direction like before the construction of the dam. Since 1990's, the wet-cross-section reached critical dimensions, which have the twofold effect of hindering flood tidal-currents and accelerating ebb tidal-currents. The channel is now strongly meandering transporting sediment in a seaward direction out of the overfilled accommodation space of the inner and central estuary. In the later, maximum sedimentation rates grew up from 8.5 to $17 \mathrm{~cm} /$ year before 1960 to $54 \mathrm{~cm} / \mathrm{yr}$ between 1960 and 1994, and declined to $1.7-8.7 \mathrm{~cm} / \mathrm{yr}$ between 1994 and 2007. These sedimentation rates are 20-135 times larger than the sedimentation rates of $0.4 \mathrm{~cm} / \mathrm{yr}$ recorded in the central estuary during the last 2600 years (Bouysse et al., 1974) and contribute to the infilling of the estuary. These sedimentation rates are significantly higher than sedimentation rates observed in the Seine River estuary (0.5 mm/yr) (Delsinne, 2005) and the Loire River estuaries
(0.4-4.2 cm/yr) (Ciffroy et al., 2003). They encompass also the 1.9 times rise in sedimentation rates of the Keum estuary (South Korea) after the construction of a dam (Kim et al., 2006). These differences may be explained by a particularly sheltered position linked with the proximity of an important source of sediment that represents the Loire Estuary.

Thus, this evolution points to a general landward filling of the estuary from 1960 to 1992, followed by a seaward filling from 1992 to 2007. The estuarine infilling of inner parts after the construction of the dam took only c.20 years (from 1970 to 1992) to be completed. This is a relatively short period of time compared for example to the estuary of the Ord River (Australia) which took 100 years to reach a new equilibrium (Wolanski et al., 2001). These two steps, a retrogradation and progradation scenario, are mentioned in the Outardes River estuary (Hart and Long, 1990); after a drastic reduction of water discharge for 18 months $\left(1800-2800 \mathrm{~m}^{3} \mathrm{~s}^{-1}\right.$ to $50 \mathrm{~m}^{3} \mathrm{~s}^{-1}$ ) and a landward sediment stepping, the water discharge decreased and the sediment stepped seaward. The Keum Estuary seems to be in an earlier stage because residual sedimentation is still oriented in a landward direction (Kim et al., 2006). Therefore, a fall of river discharges enhances in a first step landward sedimentation and when the section is sufficiently reduced, sediments settle in a seaward direction.

\subsection{Some particular characteristics}

\subsubsection{A constant fluvial sediment supply}

In most cases, the damming of rivers is at the origin of erosion of river sides or adjacent coastal areas (Chen, 2005) because the reservoirs at the back of dams trap sediment particles and limit the replenishment of adjacent coastal areas with fluvial sediment. In the case of the Vilaine Estuary, due to its lithology and historical geology, the catchment is small and old with very limited erosion. The catchment mostly provides SPM to the surrounding coastal areas and the bay at the reduced rate of $0.110^{6} \mathrm{t} / \mathrm{yr}$ (Jouanneau et al., 1999). The freshwater reservoir is almost clear of sediment as well as the river rocky bed (Crave et al., 2007). The dam is therefore not responsible for massive sediment retention. While suspended load in the bay is assumed stable, sea-level rise combined with wave activity cause salt-marshes erosion and generate further suspended load. Since the dam construction, the suspended load is now restricted to settle in the last $8 \mathrm{~km}$ section of the estuary ( $70 \mathrm{~km}$ before dam construction). Therefore, the estuary behaviour closely resembles the infilling of a tidal bay where most of the sediment is provided by the sea and salt marshes erosion, especially during summer when river discharge resumes. The inner part of the estuary being mostly filled, lower inter-tidal parts experience higher sedimentation rates sheltered of the wave activity.

\subsubsection{An accelerated reduction of salt marshes}

The increase in the frequency of flooding events enhances the erosion of salt marshes by degrading physical ground-properties. The tidal surges resulting from sea-level rise and the construction of the dam flood even more the salt marsh at each tide. The landward oriented winds, as well as the sea-level rise of about $100 \mathrm{~mm}$ since the construction of the dam, certainly enhanced the flood surge (Fig. 7). The three phenomena (tidal surge, wind surge and sea-level rise) accumulate to enhance the lateral erosion of the saltmarshes in the estuary. Despite a context of strong accumulation of sediment on the lower part of the tidal flat, upper parts undergo erosion. This situation illustrates an adaptation to the new water-base level due to sea-level rise and not a consequence of the damming of the river. 


\section{Conclusion}

The impacts of natural hydrodynamic factors such as waves and tides have been affected by human developments leading to evolution of new morphodynamic patterns as seen in the proposed hypothetical model (Fig. 7).

Climatic conditions stayed fairly stable before and after the dam construction although the wave activity could have fluctuated through the time and sea-level rose about $100 \mathrm{~mm}$ since 1970. These hydrodynamic parameters without a link with the dam lead to:

- The generation of two littoral drifts of sandy material feeding the estuary

- The erosion of salt marshes related to the onshore migration of the cheniers

Since 1970 the dam construction had a decisive role on the vertical and lateral extension of the lower tidal flat. Its direct impact is the increase of sedimentation rates due to:

- The reduction of the tidal prism leading to the fall of the tidal currents

- The reduction of the accommodation space

- The regulated fresh water discharge

The functioning of the Vilaine Estuary appeared to be closer to a bay-type environment (especially during summer).

Interplay of these parameters leading to the infill of the estuary was also observed:

- Erosion generated by wave activity and sea-level rise are kept within the estuary due to the particular sheltered position of the estuary and the new hydrodynamic conditions generated by the dam.

- The natural estuarine infill linked to the sea-level rise has been accelerated with the dam construction and developed in two steps: a landward trend before 1992 and a seaward trend after 1992. Therefore it only took c.20 years from 1970 to 1992 to complete estuarine inner-parts infill.

A more detailed and precise physical model could be constructed in the future depending on the availability of regularly acquired datasets by concerned organizations.

\section{Acknowledgements}

This project has been co-financed by the Région Bretagne (COTARMOR project) and the Conseil Géneral of Morbihan (Vivamod project). The authors would like to thank Christine Bonfiglio and Jo Brohan for financing this study. We would like to acknowledge the Institut d'Aménagement de la Vilaine (IAV) for providing tidal and discharge informations measured at the Arzal dam, the Service Hydrographique de la Marine (SHOM) for the copy of the ancient nautical chart of Beautemps-Beaupré, the archives of the Morbihan Department for scanning the aerial photo-set of year 1971 as well as Josiane Boyce and Jean-Marc Goutherot, which made possible the dedicated flight above the Vilaine Estuary. We would like to thank also Evelyne Goubert, Hervé Regnauld and Jean-Jacques Tiercelin, Dr. Ana Garcia-Garcia and an anonymous reviewer for the fruitful comments on this paper.

\section{References}

Allen, G.P., Posamentier, H.W., 1993. Sequence stratigraphy and facies model of an incised valley fill; the Gironde Estuary, France. J. Sediment. Res. 63, 378-391.
Allen, G.P., Posamentier, H.W., 1994. Transgressive facies and sequence architecture in mixed tide and wave-dominated incised valleys: example from the Gironde estuary, France. In: Dalrymple, R.W., Boyd, R.J., Zaitlin, B.A. (Eds.), Incised-valley Systems: Origin and Sedimentary Sequences. SEPM, Tulsa, pp. 225-240.

Azevedo, I.C., Duarte, P.M., Bordalo, A.A., 2008. Understanding spatial and temporal dynamics of key environmental characteristics in a mesotidal Atlantic estuary (Douro, NW Portugal). Estuar. Coast. Shelf Sci. 76, 620-633.

Bilgili, A., Proehl, J.A., Lynch, D.R., Smith, K.W., Swift, M.R., 2005. Estuary/ocean exchange and tidal mixing in a Gulf of Maine Estuary: a Lagrangian modeling study. Estuar. Coast. Shelf Sci. 65, 607-624.

Bird, E.C.F., 1993. Submerging Coasts: the Effects of a Rising Sea Level on Coastal Environments. John Wiley \& Sons, Chichester, p. 184.

Bouligand, R., Pirazzoli, P.A., 1999. Les surcotes et les décotes marines à Brest, étude statistique et évolution positive and negative sea surges at Brest. Oceanol. Acta 22, 153-166.

Bouysse, P., Chateauneuf, J.-J., Ters, M., 1974. Présence d'Yprésien, niveau transgressif et taux de sédimentation flandriens en baie de Vilaine (Bretagne Méridionale). In: Comptes Rendus de l'Académie des Sciences Série II D, pp. 1421-1424.

Bowden, K.F., 1967. Circulation and diffusion. In: Lauf, G.H. (Ed.), Estuaries. American Association for the Advancement of Science Washington, pp. 15-36.

Boyd, R., Dalrymple, R., Zaitlin, B.A., 1992. Classification of clastic coastal depositional environments. Sediment. Geol. 80, 139-150.

Cameron, W.M., Pritchard, D.W., 1963. Estuaries. In: H, M.N. (Ed.), The Sea. John Wiley and Sons, New York, pp. 306-324.

Caspert, H., 1967. Estuaries: analysis of definitions and biological considerations. In: Lauf, G.H. (Ed.), Estuaries. American Association for the Advancement of Science Washington, pp. 6-8.

Chen, J., 2005. Dams, Effect on Coasts, Encyclopedia of Coastal Science, pp. 357-359.

Ciffroy, P., Reyss, J.-L., Siclet, F., 2003. Determination of the residence time of suspended particles in the turbidity maximum of the Loire estuary by ${ }^{7} \mathrm{Be}$ analysis. Estuar. Coast. Shelf Sci. 57, 553-568.

Crave, A., Proust, J.-N., Renault, M., 2007. Cartographie sédimentaire du cours de la Vilaine: imagerie sonar et sismique. Rapport d'étude pour l'Institut d'Aménagement de la Vilaine. Institution d'aménagement de la Vilaine, p. 221.

Dalrymple, R.W., Zaitlin, B.A., Boyd, R., 1992. Estuarine facies models; conceptual basis and stratigraphic implications. J. Sediment. Res. 62, 1130-1146.

Day Jr., J.W., Hall, C.A.S., Kemp, W.M., Yàñez-Arancibia, A., 1989. Estuarine Ecology. John Wiley \& Sons, New York, p. 558.

Delsinne, N., 2005. Evolution pluri-millénaire à pluri-annuelle du prisme sédimentaire d'embouchure de la Seine. Facteurs de contrôle naturels et d'origine anthropique. Université de Caen/Basse Normandie, Caen, p. 179.

Estournès, G., Menier, D., Guillocheau, F., Le Roy, P., Paquet, F., Goubert, E., 2012. The Paleo-Etel river incised valley on the Southern Brittany inner shelf (Atlantic coast, France): preservation of Holocene transgression within the remnant of a middle Pleistocene incision? Mar. Geol. 329-331, 75-92.

Fairbridge, R.W., 1980. The estuary its definition and geodynamic cycle. In: Olausson, E., Cato, I. (Eds.), Chemistry and Biogeochemistry of Estuaries. Wiley \& Sons, New York, pp. 1-35.

Ferrier, G., Anderson, J.M., 1997. A multi-disciplinary study of frontal systems in the Tay Estuary, Scotland. Estuar. Coast. Shelf Sci. 45, 317-336.

Geyer, W., Trowbridge, J.H., Bowen, M., 2000. The Dynamics of a Partially Mixed Estuary. American Meteorological Society, pp. 2035-2048.

Goubert, E., Menier, D., 2005. Evolution morphosédimentologique de l'estuaire de la Vilaine de 1960 à 2003: Valorisation des campagnes bathymétriques. Université de Bretagne Sud, Vannes, p. 104.

Green, M.O., MacDonald, I.T., 2001. Processes driving estuary infilling by marine sands on an embayed coast. Mar. Geol. 178, 11-37.

Guilcher, A., 1958. Coastal and Submarine Morphology. J. Wiley, London, Methuen; New York, p. 274.

Guo, X., Valle-Levinson, A., 2007. Tidal effects on estuarine circulation and outflow plume in the Chesapeake Bay. Cont. Shelf Res. 27, 20-42.

Hart, B.S., Long, B.F., 1990. Recent evolution of the Outardes Estuary, Quebec, Canada - consequences of dam construction on the river. Sedimentology 37, 495-507.

Hurrell, J.W., Deser, C., 2009. North Atlantic climate variability: the role of the North Atlantic oscillation. J. Mar. Syst. 78, 28-41.

Ji, Z.-G., Hu, G., Shen, J., Wan, Y., 2007. Three-dimensional modeling of hydrodynamic processes in the St. Lucie Estuary. Estuar. Coast. Shelf Sci. 73, 188-200.

Jouanneau, J.M., Weber, O., Cremer, M., Castaing, P., 1999. Fine-grained sediment budget on the continental margin of the Bay of Biscay. Deep Sea Res. II Top. Stud. Oceanogr. 46, 2205-2220.

Kim, T.I., Choi, B.H., Lee, S.W., 2006. Hydrodynamics and sedimentation induced by large-scale coastal developments in the Keum river estuary, Korea. Estuar. Coast. Shelf Sci. 68, 515-528.

Krebs, M., 2010. Naturversuch Emssperrwerk - Wirkungsanalyse anhand von Synchrontiden. In: Bundesministerium für Verkehr, B.u.S. (Ed.), Erfassung und Bewertung des hydromorphologischen Zustandes in Wasserstraßen. Bundesanstalt für Gewässerkunde, Koblenz, p. 141.

Latteux, B., 2005. Mission d'expertise sur la modélisation hydro-sédimentaire en milieu estuarien. Institution d'Aménagment de la Vilaine, p. 39.

Levasseur, A., Shi, L., Wells, N.C., Purdie, D.A., Kelly-Gerreyn, B.A., 2007. A threedimensional hydrodynamic model of estuarine circulation with an application to Southampton Water, UK. Estuar. Coast. Shelf Sci. 73, 753-767. 
Maillocheau, F., 1980. L'envasement de l'estuaire de la Vilaine en aval du Barage d'Arzal. Département des Sciences de la Terre. Université de Nantes, Nantes, p. 65.

Martinsen, O.J., Hellandhansen, W., 1994. Sequence stratigraphy and facies model of an incised valley fill - the Gironde Estuary, France - discussion. J. Sediment. Res. Sect. B Stratigr. Glob. Stud. 64, 78-80.

Masselink, G., Hughes, M.G., 2003. Introduction to Coastal Processes \& Geomorphology. Hodder Arnold Publication, p. 896.

Menier, D., Tessier, B., Proust, J.-N., Baltzer, A., Sorrel, P., Traini, C., 2010. The holocene transgression as recorded by incised valley infilling in a rocky coast context with low sediment supply (southern Brittany, western France). Bull. la Soci. Géol. Fr. 181, 115-128.

Menier, D., Augris, C., Briend, C., 2014. Les réseaux fluviatiles anciens du plateau continental de Bretagne Sud, p. 104. Ed Quae.

Merceron, M., 1985. Impact du Barrage d'Arzal sur la qualité des eaux de l'estuaire de la Vilaine et de la Baie de la Vilaine. IFREMER, Brest, p. 31.

Morzadec-Kerfourn, M.T., 1974. Variations de la ligne de rivage armoricaine au Quaternaire. Analyses polliniques de depots organiques littoraux. Mem. Soc Geol. Min. Bretagne 17, 280 (These); Rennes.

Pethick, J., 1984. An Introduction to Coastal Geomorphology. Edward Arnold, London, p. 260.

Pethick, J., 1993. Shoreline adjustments and coastal management: physical and biological processes under accelerated sea-level rise. Geogr. J. 159, 162-168.

Phillips, M.R., Crisp, S., 2010. Sea level trends and NAO influences: the Bristol Channel/Severn Estuary. Glob. Planet. Change 73, 211-218.

Pirazzoli, P.A., 2000. Surges, atmospheric pressure and wind change and flooding probability on the Atlantic coast of France. Oceanol. Acta 23, 643-661.

Pirazzoli, P.A., Regnauld, H., Lemasson, L., 2004. Changes in storminess and surges in western France during the last century. Mar. Geol. 210, 307-323.

Pritchard, D.W. 1967. What is an estuary, physical viewpoint. In: Lauf, G.H. (Ed.), Estuaries. American Association for the Advancement of Science, Waschington D.C, pp. $3-5$.
Proust, J.-N., Menier, D., Guillocheau, F., Guennoc, P., Bonnet, S., Le-Corre, C., Rouby, D., 2001. Les vallées fossiles de la Vilaine: nature et évolution du prisme sédimentaire côtier du pléistocène armoricain. Bull. la Soci. Géol. Fr. 6, 737-749.

Russell, R.J., 1967. Origins of estuaries. In: Lauf, G.H. (Ed.), Estuaries. American Association for the Advancement of Science Washington, pp. 93-99.

Salomon, J.-C., Allen, G.-P., 1983. In: Pétroles, C.F.d. (Ed.), Rôle sédimentologique de la marée dans les estuaires à fort marnage, pp. 35-44.

Short, A.D., 1999. Handbook of Beach and Shoreface Morphodynamics. Wiley, p. 392.

Sorrel, P., Tessier, B., Demory, F., Baltzer, A., Bouaouina, F., Proust, J.-N., Menier, D., Traini, C., 2010. Sedimentary archives of the French Atlantic coast (inner Bay of Vilaine, south Brittany): depositional history and late Holocene climatic and environmental signals. Cont. Shelf Res. 30, 1250-1266.

Tagliani, P.R.A., Landazuri, H., Reis, E.G., Tagliani, C.R., Asmus, M.L., SánchezArcilla, A., 2003. Integrated coastal zone management in the Patos Lagoon estuary: perspectives in context of developing country. Ocean Coast. Manag. 46, 807-822.

Tessier, C., 2006. Caractérisation et dynamique des turbidités en zone côtière: l'exemple de la région marine Bretagne Sud. Laboratoire de Physique Hydrodynamique et Sédimentaire. Université de Bordeaux 1, Bordeaux, p. 400.

Traini, C., Menier, D., Proust, J.N., Sorrel, P., 2013. Transgressive systems tract of a riatype estuary: the Late Holocene Vilaine river drowned valley (France). Mar. Geol. 337, 140-155.

Winterwerp, J.C., Wang, Z.B., Stive, M.J.F., Arends, A., Jeuken, C., Kuijper, C., Thoolen, P.M.C., 2001. A newmorphological schematization of the western Scheldt Estuary, The Netherlands. In: 2nd IAHR Symposium On River Coastal and Estuarine Morphodynamics, Obihiro,Japan, pp. 525-533.

Wolanski, E., Moore, K., Spagnol, S., D'Adamo, N., Pattiaratchi, C., 2001. Rapid, human-induced siltation of the macro-tidal Ord river estuary, western Australia. Estuar. Coast. Shelf Sci. 53, 717-732.

Woodruff, J.D., Geyer, W., Sommerfield, C., Driscoll, N., 2001. Seasonal variation of sediment deposition in the Hudson river estuary. Mar. Geol. 179, 105-119. 